\title{
The Impact of Leisure Agriculture on Package Group Tours: A China's New Tourism Laws Perspective
}

\author{
Mei-Ying Lan', Ta-An Hung2* \\ ${ }^{1}$ Department of Tourism and Leisure Management, Chung Chou University of Science and Technology, Taiwan \\ ${ }^{2}$ Bachelor Program of Law, Toko University, Taiwan \\ Email: ^hungtaan@gmail.com
}

How to cite this paper: Lan, M.-Y. and Hung, T.-A. (2019) The Impact of Leisure Agriculture on Package Group Tours: A China's New Tourism Laws Perspective. Open Access Library Journal, 6: e5141. https://doi.org/10.4236/oalib.1105141

Received: December 24, 2018

Accepted: February 11, 2019

Published: February 14, 2019

Copyright $\odot 2019$ by author(s) and Open Access Library Inc.

This work is licensed under the Creative Commons Attribution International License (CC BY 4.0).

http://creativecommons.org/licenses/by/4.0/

\begin{abstract}
In recent years, China's package group tours have a strong consumption capacity, which is conducive to the integration of various industries. In particular, package group tours in leisure agriculture are different from traditional tourism development and package group tours are developing rapidly. Among them, leisure agriculture in the context of collective tourism is conducive to market demand, and on the other hand, it becomes a new type of agricultural production and tourism and tourism because of the needs of rural economic development. However, since the implementation of the "New Tourism Laws" in China in 2013, travel agencies have been banned from arranging shopping trips, which will have an impact on the development of leisure agriculture and rural tourism. Through literature review, this study analyzes the significance of developing leisure agriculture in the context of current package group tours in China. According to the typical case analysis of rural tourism in China, we found the main problems of the new tourism laws in the process of China's leisure agricultural tourism planning, as a mirror for the future development of leisure agriculture. This study also proposes countermeasures and suggestions for the future development path of China's leisure agriculture under the new tourism laws.
\end{abstract}

\section{Subject Areas}

Law

\section{Keywords}

New Tourism Laws, Package Group Tours, Leisure Agriculture, Rural Tourism 


\section{Introduction}

Since China's economic reforms, the demand for various economic and trade activities with countries around the world has arisen. There are many world-famous scenic spots in China, and the Chinese authorities know that "sightseeing tourism is a smoke-free industry" (Jorgensen et al., 2017) [1]. With the increasing scope of China's open economic reforms, the development of tourism and tourism has shown a rapid growth trend.

In addition to enjoying places of interest and experiencing local customs, the tour also includes tasting local flavors and buying folk specialties. Because many of the related raw materials come from agricultural products, it naturally becomes the driving force for the production and marketing of local agricultural products and agricultural tourism, which in turn drives the development of local leisure agriculture (Liu et al., 2018) [2]. In other words, the rise of China's leisure agriculture is beginning to show its vitality under the trend of the times. In particular, China officially announced on December 28, 2005, that the theme of China's tourism in 2006 was "2006 China Rural Tour", under the leadership of "New Countryside, New Tourism, New Experience, New Fashion (McMahon, and Thorsteinsdottir, 2010) [3]. There are new development trends.

With the development and practice of China's tourism industry, package group tours have become the reorientation of tourism development strategy in the new era and the new normal. Song and Li (2014) [4] reported that China's current development of package group travel, the direction is right, we must continue. Chan et al. (2016) [5] also reported that the entire tourism facilities and services will help to develop rural, leisure and package group tours. In recent years, China's leisure agriculture reception and business income have increased by more than $15 \%$ every year. It is estimated that in 2018, leisure agriculture will be close to 590 billion Yuan (Wu et al., 2017) [6]. The five development concepts of "Group Travel and Innovation, Coordination, Green, Openness, and Sharing" are highly compatible, and have the inherent advantages of connecting and integrating development with major national strategies such as "Beautiful China, Healthy China, and Ecological Civilization Construction" (Masahiro and Jiang, 2009) [7]. The leisure agriculture under it will also become the mainstream model for China to cope with the large-scale demand for mass tourism in the well-off society. However, China began to implement the Tourism Law of the People's Republic of China on October 1, 2013, and travel agencies forced a maximum penalty of 300,000 yuan for forced shopping (Cao, 2015) [8]. Clear regulations have been made on tourist chaos such as "zero-negative group fees", forced shopping, and uncivilized behavior of tourists. This study analyzes the typical case of rural tourism in China under the "New Tourism Law" and finds out the main problems in the tourism planning process of leisure agriculture as a mirror for the future development of leisure agriculture. 


\section{Literature Review}

\subsection{China's Leisure Agriculture and Package Group Tour}

As an emerging agricultural development model, leisure agriculture has a broad market prospect and will surely become the growth point of the rural economic development center. Leisure agriculture is conducive to the overall rural land use policy of rural tourism and is also conducive to the activation of tourism assets in underdeveloped areas (Chen et al., 2012) [9]. Leisure agriculture is conducive to coordinating all kinds of resources in the domain, efficient allocation, and promoting the rapid and stable development of the agricultural economy (Feng, 2012) [10]. Leisure agriculture will become an important starting point for coordinating urban space, production space and ecological space, and become the most important project for people's livelihood.

The leisure agriculture under the Chinese group travel is accompanied by the transformation and upgrading process of tourism from traditional sightseeing tours, such as rural leisure vacations (Yang et al., 2014) [11]. Leisure agriculture under group travel is a new regional tourism development concept, which is of great significance to all aspects of social and economic development.

After more than 30 years of development, China's tourism industry has developed into a civilian production industry with extensive participation in employment and entrepreneurship and has become a whole modern industry. The number and quality of tourism resources in the group tourism industry are general, and even the regions lacking tourism resources provide a possibility of tourism development (Ouyang et al., 2013) [12]. Rural tourism resources such as "green mountains and blue mountains and white clouds" and "special culture and lifestyle" have become tourism serious, necessary conditions for transformation and upgrading (Sun et al., 2017) [13].

Tourism can improve poverty, not only can provide a considerable number of jobs for the countryside, but also increase the economic income of farmers. At the same time, tourism has also opened up the channels for farmers to accept new things and ideas, and it is both material and spiritual to improve poverty (Ng, 2011) [14]. The development of rural leisure agriculture can effectively increase the effectiveness of poverty improvement, improve the rural ecological environment, and improve infrastructure construction (Jorgensen et al., 2017) [1]. The development of rural leisure agriculture can also promote the tourism revolution, road construction, farmland transformation, and indeed build beautiful villages.

\subsection{China's New Tourism Law}

China's draft tourism law defines the concept of "tourism" as "the tourism referred to in this Law refers to natural people's leisure, entertainment, sightseeing, vacation, visiting relatives and friends, medical care, shopping, attending conferences or engaging in economics, culture, sports, Religious activities, leaving the place of usual residence to other places, staying for no more than 12 
months, and the main purpose is not to get paid through the activities undertaken" (Zuo and Huang, 2018) [15]. Some activities such as visiting relatives and friends, attending conferences and engaging in economic and social activities should not be part of tourism activities. At the same time, defining official activities such as attending meetings as misunderstandings that tourism is also likely to cause public loans is proposed to be revised.

The Tourism Law was a legislative project initiated at the beginning of the reform and opening up. However, because China's tourism industry was still in its infancy, the relevant parties were not aware of some critical issues involved in the legislation. By the end of 2011, there were more than 20,000 scenic spots in China, with more than 20,000 travel agencies, more than 10,000 star-rated hotels, more than 13 million direct tourism employees, and more than 2.6 billion domestic tourists (Yan et al., 2018) [16]. Inbound tourism exceeded 135 million person-times, and citizens outbound tourism exceeded 70 million person-times (Shen et al., 2017) [17]. China's domestic tourism market ranks first in the world, and the number of inbound tourists and citizens' outbound tourism consumption ranks third in the world.

The Tourism Law is the general term for adjusting the legal norms of various social relations in the field of tourism activities, that is, the sum of various legal norms that are subject to adjustment of legal tourism relations. It includes the narrowly-defined "Law of the People's Republic of China" and other relevant laws and laws regulating various legal relations in tourism activities, as well as the one-way tourism administrative law and departmental regulations enacted by the State Council and the competent tourism authorities (Zuo and Huang, 2018) [15]. China began to implement the "Law of the People's Republic of China" on October 1, 2013, and travel agencies forced a maximum penalty of 300,000 yuan for forced shopping. Clear regulations have been made on tourist chaos such

as "zero-negative group fees", forced shopping, and uncivilized behavior of tourists (Qian et al., 2018) [18].

With the rise of universal tourism, people's travel methods have also undergone tremendous changes. The quality of tourism and reputation in a region depends not only on the quality of services such as travel agencies, hotels, scenic spots but also on the whole environment of the entire region. Leisure agriculture and rural tourism around the city expand the tourist space of the people, convenient and diversified (Sun and Zhao, 2017) [13]. The choice of tourism has dramatically enhanced the willingness to travel and the frequency of tourism and has comprehensively improved the welfare of national tourism and the happiness index of people's lives.

\section{Case Study: Xihua Village in China}

Huaxi Village, Jiangyang City, Jiangsu Province, has become a famous modern model village in China with its leisure agriculture. Since 2001, Huaxi Village has helped lead the development of 20 surrounding villages and built a large Huaxi 
area with an area of 35 square kilometers and a population of 30,340 (Shi, 2015) [19]. It consists of a village with a green hill, a lake, a highway, a waterway, a tunnel, and a heliport. The rise of Huaxi Village is the epitome of China's reform and opening up: in the 1980s, the spring breeze of reform and opening up blew into the south of the Yangtze River, and the rural areas abolished the people's commune system and implemented the "family contract responsibility system" (Wu et al., 2017) [6]. Although the "Huaxi Brigade" at that time was renamed "Huaxi Village", it still adhered to the collective economy. There are more than 80 famous scenic spots in Huaxi Village. Huaxijinta is its landmark building, with seven levels and seventeen floors and a height of 98 meters s (Qian et al., 2018) [18].

Beginning in 2012, Huaxi's agriculture has transformed into green agriculture, ecological agriculture, and tourism agriculture. The Huaxi Urban Agriculture Demonstration Park is mainly composed of a horticultural center, pollution-free vegetables and fruits, animal husbandry and aquatic products, flower seedlings, and rice and wheat oil bases. The total area of intelligent greenhouses is more than 12,000 square meters. In 2012, the total income of Huaxi Village was 52.45 billion. Huaxi Group, a subsidiary of Huaxi Village, was assessed by the Ministry of Agriculture as a large-scale township enterprise in the country in 1996 (Ouyang et al., 2013). Huaxi won the "National Civilized Villages and Towns", "National Cultural Model Village Demonstration Sites", and "National Townships". The honorary title of "Advanced Unit of Enterprise Ideological and Political Work" and "National Advanced Enterprise of Township Enterprises" is also known as "the first village in the world" (Shi, 2015) [19].

However, because of the implementation of China's new tourism law, travel agencies can no longer force groups of group travelers to shop. Therefore, the leisure agriculture tourism of Xihua Village in Jiangsu Province has launched the "Farmers Fun Tourism, Rural Scenery Tourism, Leisure Ecotourism" tourism products, which meets the needs of urban people to experience farm life and pursue leisure vacation. (Chan et al., 2016) [5]. Tourists live in traditional farmhouses, using traditional pots and traditional kitchen utensils.

Visitors fish their fish, pick vegetables themselves, and cook their fruits and vegetables. Visitors can not only taste the fresh farmhouse food, but also feel the freshness and fun of the rural life, enrich the content of leisure agriculture development, and provide an effective way to get rich in Huaxi Village.

\section{Discussion}

After years of development, China's leisure agriculture has formed many leisure agricultural brands with local characteristics and certain cultural influence. However, overall, there are still many problems in the development of China's leisure agriculture. The rural natural scenery is crucial for the development of leisure agriculture, but an essential element in the development of leisure agriculture should be agricultural culture. China is an ancient agricultural country 
and a primarily agricultural country. It has formed an agricultural culture with Chinese characteristics in long-term agricultural cultivation. To develop leisure agriculture, it is necessary to extract agricultural culture that can represent local characteristics. If it is merely relying on the natural agricultural environment and landscape, then it is difficult to maintain long-term development. Only by forming a unique and irreplaceable characteristic culture can the brand effect be exerted and local leisure agriculture can continue to develop at a high level.

The reason why China's new tourism law has an impact on the tourism income of leisure agriculture groups of travel agencies is that farmers and rural gas industry are the chief operating entities of China's leisure agriculture. Although the number of peasants is large, the level is not high, and there are no reasonable rules and scientific management in operation. Many leisure resorts, country hotels, farmhouses, etc. are simple imitations, extensive management, and some only pay attention to immediate interests, blind development, regardless of long-term development, low-cost social Lac and even smuggling behavior sometimes exposed, these are The negative factors that restrict the development of leisure agriculture. Besides, most leisure agriculture only stays in tourism and tourism during the production and operation process, at the expense of natural resources to reduce operating costs, neglecting the foundation of "ecological agriculture", causing environmental pollution in the surrounding area. Will affect the sustainable development of leisure agriculture.

Even though the new tourism law has been enacted, leisure agriculture tourism is actively being developed throughout China. However, in practice, the Chinese government has placed more emphasis on introducing several large-scale projects with high returns and high influence, rather than putting too much experience on leisure agriculture that can provide more jobs. Due to the lack of sustained support from the government, leisure agriculture in many places has strong momentum in the initial stage. In the later period, due to the lack of policy support, it is difficult to implement it, and the forming effect will be significantly reduced. This will not only promote local agricultural development but will also waste a lot of valuable resources. Besides, the government's support funds for leisure agriculture are not in place, and the operators lack the channel of the West Hard, which makes the leisure agriculture mostly small in scale, low in grade, poor in equipment, low in popularity and unattractive.

\section{Conclusions and Suggestions}

Many enterprises manage leisure agriculture, such as ecological agriculture parks, agricultural science and technology parks, and agricultural product exhibition centers. However, in general, leisure agricultural products are single, and lack of quality products, which cannot fully meet the needs of the modern tourism market, and it is difficult to increase the revisit rate. In particular, the implementation of the new tourism law has made clear regulations on tourist chaos such as "zero-negative group fees", forced shopping, and uncivilized behavior of 
tourists, and it is necessary to develop new tourism projects. Taking the Sightseeing Agricultural Park as an example, the models and patterns of agricultural parks in all countries of the world are similar. They use existing ponds, orchards, farmland, farms, and slightly renovated and beautified to build several artificial landscapes. Tourists' sightseeing programs are limited to simple activities such as picking fruits, eating farm meals, and fishing. This kind of leisure agriculture that blooms everywhere is a typical low-level development. The project has a single function, and the product has no taste and characteristics. In particular, there are fewer agricultural production activities and recreational activities for visitors to participate in. At the same time, there are problems such as less investment, small-scale, and scattered regional distribution, which makes it challenging to retain repeat customers.

In response to the implementation of the new tourism law, China's development of recreational agriculture group tourism should pay attention to the construction of scenic spots, theme creation, and setting of scenarios. In the initial design, look for something different, or introduce different products, or update the planting method to achieve unique results. Leisure agriculture introduces modern agriculture into the scenic spot, and promotes regional agricultural upgrading, allowing tourists to find the "attractiveness" outside the scenery in the fields. Different visitors can experience different rural experiences through the experience of recreational agriculture projects in the scenic area. For example, older tourists who see farming equipment will evoke memories of their childhood. Young tourists will see the ecological outlook of the park and will rise to the pursuit of self. This is more conducive to the return of tourists' emotions, which in turn increases the sense of identity of tourists.

\section{Acknowledgements}

The authors would like to thank the anonymous referees for your valuable connects and suggestions.

\section{Conflicts of Interest}

The authors declare no conflicts of interest regarding the publication of this paper.

\section{References}

[1] Jørgensen, M.T., Law, R. and King, B.E. (2017) Understanding the Past, Anticipating the Future-A Critical Assessment of China Outbound Tourism Research. Journal of Travel \& Tourism Marketing, 34, 880-891. https://doi.org/10.1080/10548408.2016.1220889

[2] Liu, Y.L., Ho, L.M. and Liu, F.Y. (2018) The Brand Management Evaluation Indicators Model of Agri-Tourism Farms: A Core Competence Perspective. Open Access Library Journal, 5, 1-9. https://doi.org/10.4236/oalib.1104827

[3] McMahon, D. and Thorsteinsdottir, H. (2010) Regulations Are Needed for Stem Cell Tourism: Insights from China. American Journal of Bioethics, 10, 34-36. 
https://doi.org/10.1080/15265161003754080

[4] Song, X. and Li, H. (2014) An Analysis on Rural Tourism Development Model in Yi County of Huangshan City. Asian Agricultural Research, 6, 63-65.

[5] Chan, J.H., Iankova, K., Zhang, Y., McDonald, T. and Qi, X. (2016) The Role of Self-Gentrification in Sustainable Tourism: Indigenous Entrepreneurship at Honghe Hani Rice Terraces World Heritage Site, China. Journal of Sustainable Tourism, 24, 1262-1279. https://doi.org/10.1080/09669582.2016.1189923

[6] Wu, H.-C., Cheng, C.-C. and Ai, C.-H. (2017) A Study of Experiential Quality, Equity, Happiness, Rural Image, Experiential Satisfaction, and Behavioral Intentions for the Rural Tourism Industry in China. International Journal of Hospitality \& Tourism Administration, 18, 393-428.

https://doi.org/10.1080/15256480.2017.1289138

[7] Masahiro, U. and Jiang, H.W. (2009) Changing Adaptive Strategies of Two Li Ethnic Minority Villages in a Mountainous Region of Hainan Island, China. Tonan Ajia Kenkyu, 47, 348-362.

[8] Cao, X. (2015) Challenges and Potential Improvements in the Policy and Regulatory Framework for Sustainable Tourism Planning in China: The Case of Shanxi Province. Journal of Sustainable Tourism, 23, 455-476. https://doi.org/10.1080/09669582.2014.957207

[9] Chen, Y.M., Liu, F.Y., Ho, L.M. and Lin, T.M.Y. (2012) Development of Word-ofMouth Elasticity Measures for Tourism Product Categories. Psychology, 3, 722-728. https://doi.org/10.4236/psych.2012.39109

[10] Feng, X.H. (2012) From Labor to Capital: Tourism and the Poverty of Resources in Rural Ethnic China. Urban Anthropology \& Studies of Cultural Systems \& World Economic Development, 41, 329-365.

[11] Yang, C., Qi, W. and Liu, Q. (2014) On New Landscape Agriculture in Yunnan Flatland Area. Asian Agricultural Research, 6, 41-43.

[12] Ouyang, H., Wu, H.S., Liu, A.Q., Yu, H. and Fu, H.M. (2013) Practice of Developing Low-Carbon Leisure Agriculture in Agricultural Sci-Tech Experiment and Denomstration Park: A Case Study of Xinglong Tropical Botanical Park. Asian Agricultural Research, 5, 39-42.

[13] Sun, G.D. and Zhao, L. (2017) Models for Evaluating the Developing Performance of Tourism Economy with Intuitionistic Fuzzy Information. International Journal of Knowledge Based Intelligent Engineering Systems, 21, 257-263. https://doi.org/10.3233/KES-170369

[14] Ng, M.K. (2011) Strategic Planning of China's First Special Economic Zone: Shenzhen City Master Plan (2010-2020). Planning Theory \& Practice, 12, 638-642. https://doi.org/10.1080/14649357.2011.626316

[15] Zuo, B. and Huang, S. (2018) Revisiting the Tourism-Led Economic Growth Hypothesis: The Case of China. Journal of Travel Research, 57, 151-163. https://doi.org/10.1177/0047287516686725

[16] Yan, L., Xu, J. and Zhou, Y. (2018) Residents' Attitudes toward Prostitution in Macau. Journal of Sustainable Tourism, 26, 205-220. https://doi.org/10.1080/09669582.2017.1338293

[17] Shen, H., Luo, J. and Zhao, A. (2017) The Sustainable Tourism Development in Hong Kong: An Analysis of Hong Kong Residents' Attitude towards Mainland Chinese Tourist. Journal of Quality Assurance in Hospitality \& Tourism, 18, 45-68. https://doi.org/10.1080/1528008X.2016.1167650

[18] Qian, J., Law, R. and Wei, J. (2018) Effect of Cultural Distance on Tourism: A Study 
of Pleasure Visitors in Hong Kong. Journal of Quality Assurance in Hospitality \& Tourism, 19, 269-284. https://doi.org/10.1080/1528008X.2017.1410079

[19] Shi, X. (2015) Factors Influencing the Environmental Satisfaction of Local Residents in the Coal Mining Area, China. Social Indicators Research, 120, 67-77. https://doi.org/10.1007/s11205-014-0584-Z 